\title{
A Forum of Questions for Active Viewing, Learning and Creating on Screen(s) During a Global Pandemic
}

Elisa Frasson, Independent researcher

Marisa C. Hayes, Artist, curator, scholar

Marco Longo, Film critic, programmer

Ariadne Mikou, Artist-scholar

Katja Vaghi, Independent scholar

Keywords: pandemic, online, screendance, collaboration, community, perception, labour/market, digital classroom, aesthetics of disappearance, pandemic gaze

\section{Introduction}

This contribution proposes a forum of questions in order to reflect on the reception, creation, and distribution of dance media online during the global pandemic. It is the result of a collaborative initiative undertaken by a group of five interdisciplinary dance and film scholars and artists based in Europe-specifically France, Germany, Greece, and Italy - who met weekly on Zoom throughout the summer of 2020 to exchange ideas, concerns, and projects related to choreography and screens during lockdown. A shared Google doc allowed all contributors to add their own questions and comments, later discussed live during virtual meetings conducted in English, which for the majority of us is not our native language. Some of us already knew each other, while others had never met. An additional shared document mapping dance-related works made or adapted for the screen ${ }^{1}$ during Europe's initial lockdown enabled us to gradually share ideas and exchange different viewpoints. Recognizing our diverse backgrounds, approaches, and geographic locations as a strength, the following forum of questions does not assume that there is any one established definition of screendance or experience of the pandemic. Instead, it seeks to build upon a shared interest in screendance to pose questions that extend to many types of dance media and screen experiences that arose and continue to arise within the context of the pandemic.

The decision to use questions as a structure for this contribution was key. While recalling and orienting the topic of discussion as our shared methodology, questions inspire autonomous reflection and do not seek to impose a single response. They provide a wide girth for different points of view and considerations of complex issues, which vary according to many factors, including geographic location, economic disparities, subjectivity and personal tastes, technological access and more. Currently, the forum of 
questions is structured in large groups according to topic and numbered sequentially in each of these categories. However, this structure does not suggest a hierarchy, but instead proposes a way to navigate the document and follow the cross-references that appear in multiple points of the hypertext. This proposes a horizontal approach to reading the text-a web of sorts-as opposed to reading in a linear fashion. The order of the categories is random, but does tend to follow a logic that proceeds from the personal to the collective. The partial use of the first person is an intentional choice in order to underscore subjectivity, as well as to provide a phenomenological way of reading.

The importance of pre-existing screendance scholarship, which has already drawn on the exponential rise of screens and electronic media in our daily lives, became a recurring topic during our exchanges. In contrast to certain specificities that arose during the ongoing pandemic, the following general introductory questions seek to underscore the relevance of established dialogues in the screendance community to further enhance discussions of screen-based work at the present time.

- How does dance mediated via a screen convey a singularity of the moment?

- How are diverse uses of screens embodied in narrative production and configured in collaborative approaches for knowledge building and sharing?

- To what extent can we speak of a community ${ }^{2}$ born from the screen?

- What happens when the codes of live art are introduced to online space- more specifically, when the aesthetics of disappearance ${ }^{3}$ that make online content ephemeral on social media networks (Instagram, Facebook stories, etc.) were intensified during the first lockdown in Europe?

- Have the limits of screendance been reached ten years after the claim that "Screendance has not yet been invented"?

Following this brief introductory set of questions, the remainder of the forum is dedicated to questions that specifically emerged during the pandemic as a result of viewing, making, or sharing screen-based choreography online. Our references are nonexhaustive, and based on personal experiences in our respective locations. They predominantly cover the timespan that dates from the first lockdown in Europe through the second pandemic wave (approximately March 2020-October 2020). It is our hope that these questions will serve as a tool to generate open and diverse perspectives on the experience of screens and dance media during this time and in the future.

\section{Perception}

1. When a body is not a body: What happens to an isolated body viewing an image of a body or bodies? 
2. How can we cultivate kinaesthetic empathy through performing agents ${ }^{5}$ on screen? What type(s) of somatic awareness do we cultivate with increased screen use? (link with EDUCATION/Q2)

3. Am I feeling another type of body after so much screen time?

4. How has the perception of the other's body changed through online devices? Is it possible that the other's body is perceived for the way(s) it occupies the frame, for its partial invisibility, or for the interface with which its image is mediated?

5. How does the blurring of online/offline boundaries affect our perception of a work of art (in this case, screendance)?

Touch

1. Are there different levels of touch (real versus imagined)?

2. Does dance mediated through the screen create somatic awareness? And if so, how?

3. If touch is mutually felt by both the giver and the receiver, how does this relation change through the screen?

Screen

1. What are the implications of curated and non-curated online spaces? What does each propose? (link with ECONOMY/Q12)

2. Do online performances help build spectatorship for live art or do they actually contribute to diminishing the public when the former becomes accustomed to easily accessed art from home? (link with ECONOMY/Q12)

3. How does quarantine influence the form and production of screendance? How does the rise in online dance media influence, or not, awareness of and access to screendance?

4. How did the sudden popularity of screendance production and online dissemination during the shift from live festival events to individual screens affect/influence a lay audience, as well as the art form itself?

5. Has our understanding of screendance changed? Has it perhaps become more precise or open? And does the quantity of dance media online pose a threat to the specificity of screendance?

6. What are the roles and responsibilities of screendance experts with regards to the sudden surge of screendance during the pandemic?

7. Does a work for screen age more quickly than one for the stage? 
8. Do archived performances appear to age more quickly due to evolutions in camera and recording technology (with the influx of online material and technological variations being more visible during the pandemic)?

9. Are new screendance communities being formed online during a time when the world is largely staying at home?

10. To what extent has the use of screens challenged the concept of location? And to what extent have screen spaces been translated into screen places? ${ }^{6}$ (link with LABOUR/Q4)

\section{Education}

1. Are there procedures or requirements for opening a digital classroom? (link with ECONOMY/Q1)

2. How does teaching screendance workshops on Zoom and other online platforms allow for new sensorial and creative approaches (for example, focus on sound or development of imagination)? (link with PERCEPTION/Q2)

3. Do such platforms encourage alternate approaches to dance learning?

4. How do Zoom and other online platforms build on and/or depart from dance pedagogy's traditional focus on physical contact and oral transmission?

\section{Aesthetics}

1. Is there a common aesthetic or aesthetics in dance media that has surfaced during the pandemic (exquisite corpse videos, aesthetics of suffering and/or containment)? When collaborating from a distance, what type of variations of the exquisite corpse, as opposed to other narrative and formal possibilities, have proliferated?7 And why?

2. Is there an aesthetics of intimacy that emerged during the pandemic via the sharing of personal home spaces online, self-representation, framing options, etc.?

3. What is the role of touch as a choreographic motif in screendance during the isolation experienced during the pandemic?

4. Is there an aesthetics of hyperactivity manifested in social media (Facebook and Instagram stories, etc.)? (link with TIME/Q2)

5. Is there already a new aesthetic shift occurring in screendance as an outcome of the saturated (mis)use/alternative use of technology? 
6. Did the role of low-tech personal equipment (such as webcams) become more commonplace in screendance production during the pandemic and thereby impact the appearance of images, sounds, etc.?

7. Does the broadly/widely accessed use of technology redefine the distinction between amateurism and professionalism during quarantine?

8. What is the role of live-streaming and editing for screendance production during the pandemic?

9. Do the aesthetics of television reality shows affect the image that the audience receives during the live streaming of dance performances-especially during the second wave of the pandemic?

10. What happens when the gaze of the filmmaker is absent or filtered by Zoom/Skype?

11. Did ecological considerations shift the look and creation of screendance projects that emerged during the pandemic, as questions of environmental security, our relationship to animals, and climate change were often underlined in relation to the pandemic?

12. Can the extended online circulation of screendance during the lockdown serve as a tool to embrace diversity of gender, race, and class?

Space

1. What types of hierarchies does the visual composition of the online public and shared space (for instance, during a Zoom meeting) generate?

2. What new political and social dimensions does online space acquire during a time of quarantine and curfews?

3. Is it relevant to speak about an economy of space in relation to screendance work created under quarantine? (link with ECONOMY/Q10)

4. How does the context of home-viewing during quarantine impact the experience of transmission from screen to viewer, as opposed to the collective viewing experience in a cinema or at a festival?

5. What architectural motifs in domestic and intimate spaces were mediated on screen during live video chats (e.g. Zoom classes, meetings and events) and screendance works?

Time

1. How does perception of time in a changing lived experience during the pandemic impact viewing and creating works of screendance? 
2. Does the pressure to be productive from home hamper creative impulses and rhythms? During the quarantine is there an increased urgency to be present and productive via the screen and how does this presence manifest? (link with AESTHETICS/Q4 \& LABOUR/Q2)

\section{Narratives}

1. Is the pandemic a theme, a production context, or both?

2. Did some artists focus on social distancing as a theme? If so, what were the challenges?

3. Why did some screendance projects attempt to 'neutralize' the domestic space while others completely ignored it?

4. Can screendance be a form of escapism from the psychological pressures of the pandemic?

5. Is there a sense of urgency to create and share via the screen that emerges during quarantine? Was screendance used as a tool of asserting/declaring/expressing presence? (link with TIME/Q2)

6. Could the reduction of physical distance through the screen be considered a form, a topic of narration, or a task?

7. What has been the role of the screen in projects of reenactment made in distance and across diverse bodies during the pandemic? ${ }^{9}$ Could projects related to dance transmission by distance become part of new narratives constructed during the pandemic (as for instance in Corner Studies by Trisha Brown Dance Company)?

\section{Society}

1. Does being present on the screen help us as individuals, as well as institutions, to feel that we exist in relation to others?

2. Is there a new type of rituality that occurred during the shift from the public sphere into the private sphere that was introduced via the screen? What kind of online codes of conduct have emerged during the pandemic, in terms of gestures, clothing, and representation of the self and its (architectural) surroundings?

3. To what extent can screen-enabled communication substitute for the physical distance experienced between bodies?

4. How does access to art online affect society's perception of dance media and its role during times of crisis? 
5. Has the migration of dance events online (streaming, conferences, interactive discussions) increased the possibilities of audience participation?

6. How does teaching dance online erase or create barriers (geographic or others) that impede or facilitate students' access to learning opportunities? (link with POLITICS/Q4)

\section{Labour}

1. What are the responsibilities and rights of institutionally contracted performance artists regarding their intellectual property and the online, often free distribution of their performance recordings? (link with ECONOMY/Q3)

2. Has the pandemic pushed the notion of precarity and hyper-productivity to its limit? (link with TIME/Q2)

3. How did some artists seize the pandemic as a context to advance ideas about uselessness and unproductivity? ${ }^{10}$

4. How did the imposed quarantine create a surge in the collaborative work of screendance making? (link with SCREEN/Q10 \& ECONOMY/Q8)

5. In this time of physical and social distancing, to what extent have screens influenced research on dance and brought greater visibility to the labor behind the production process (e.g. migration of live dance and choreographic practice to screen/online public space as for instance in Modes of Captures symposium)?

\section{Economy-Market-Industry-Production}

1. Who controls the online labor market of independent dance educators? How is it controlled? Does it need to be controlled? (link with EDUCATION/Q1)

2. What are the implications of free access to dance online (performance documentation as well as dance made for the screen) for the artists as well as the (virtual) audience?

3. How does the pandemic influence the relationship between artists, curators and institutions? (link with LABOUR/Q1)

4. There is an array of funding available for the digitalization of the performing arts. As artists, how should we respond to this surge?

5. How does monetization work online and to whose advantage?

6. When pre-recorded performances become available online, how do the rules of distribution change?

7. How do we create a fair and sustainable framework for screening fees online given the specificity of the virtual context (all access at any moment for at least 
a set period of time-as opposed to a single screening) and the international disparity between cultural budgets and incomes?

8. How do we create feasible, organized, temporary and long-term structures for screendance productions during this time? How is it possible to proceed with equitable actions?

9. Have professional and human relationships changed within audiovisual production, and as a result, in screendance production? What changes have affected the creative process, both in pre-production and during production? (link with LABOUR/Q4)

10. Is it relevant to speak about an economy of production costs in relation to screendance works created under quarantine? (link with SPACE/Q3)

11. Will dance festivals and institutions (re)embrace the field of screendance considering the growing tendency towards interdisciplinary formats such as video on demand or live streaming ${ }^{11}$

12. What considerations cannot be ignored when organizing an online festival in order to protect the works, to enhance the artists and the curators' framework and to guarantee public accessibility? (link with SCREEN/Q1 \& Q2)

\section{Politics}

1. How does screendance work challenge, enforce, or ignore local and international pandemic policies? ${ }^{12}$

2. How do recently created works of screendance contribute to political dialogues regarding the pandemic and international affairs ${ }^{13}$

3. Can online campaigns (videos made through and for solidarity such as Unesco's ResiliArt, \#ArtistsAreNecessaryWorkers and Culture and Its Workers) and viral videos mobilize and create political awareness?

4. Are visibility and representation related to internet connectivity? (link with SOCIETY/Q6)

\section{After-Question(s)}

This forum of questions was produced in order to encourage reflections regarding the acts of viewing, creating and sharing choreography on screen. We hope that it has contributed in some small way to the democratization of active viewing, as well as to the consideration of the ethics associated with responsible distribution and sharing. Throughout the global pandemic, the screen remains a means of perceiving and reimagining the body and its environment. It continues to be a potential site for 
knowledge-making, telling a story, empathizing, connecting with others, as well as protesting or raising socio-political awareness. In this respect, is there something that has shifted? True to the structure of this forum, we would like to conclude with one further question regarding what may be a common yet unconscious experience. As we grow further accustomed to connecting, engaging, creating, and looking at the world from home: Is there such a thing as a pandemic gaze?

\section{Biographies}

Elisa Frasson is an Italian researcher interested in dance and sound ecosystems. With extensive experience in the organizational context of screendance events, dance in urban spaces, and in mentoring students in creating their own projects, she is a freelance dance event curator and educator for independent and institutional projects between Italy and the UK. She is cofounder of the nomadic screendance platform [SET.mefree] Dance \& Movement on Screen and of the Italian cultural association V.e.N.e.. In 2020 she researched the Italian dance scene during the pandemic, visible in her latest publication 'As the words are touching us. Reconsidering some No Manifestos in the light of the present pandemic' (Dune Journal Vol. 1 n. 2, 2020). Elisa is a PhD candidate in Dance Studies (Roehampton University, London) and is currently based in Berlin.

\section{Email: elisaelifrasson@gmail.com}

Website: https://elisafrasson.weebly.com/

Marisa C. Hayes is a Franco-American artist, scholar and curator working at the crossroads of moving images and the performing arts. Much of her work focuses on explorations of screendance, particularly with regards to its pedagogy and curation. She is the founding co-director of the Festival International de Vidéo Danse de Bourgogne in France, an annual platform that is currently preparing its 13th edition. She also curates screendance for the National Choreographic Development Center in Paris and Theatre Freiburg in Germany. She teaches screendance practice, theory, and history in higher education internationally, as well as for various public outreach organizations. Her screendance publications include the book The Oxford Handbook of Screendance Studies (ed. Douglas Rosenberg), The International Journal of Screendance, and the book Art in Motion: Current Research in Screendance, which she co-edited for Cambridge Scholars. Her own screendance films won the Susan Braun Award (New York Dance Films Association) and Pentacle Movement Media's summer video dance prize. 


\section{Email: marisa@videodansebourgogne.com}

Website: http://www.marisahayes.com/resume.html and https://videodansebourgogne.com/

Marco Longo is an Italian filmmaker, independent producer, film critic and programmer, based in Milan. He graduated from a film directing program (Civica Scuola di Cinema Luchino Visconti, Milan) and has an additional background in literature (Università degli Studi, Pavia). In 2018 he co-founded the production company Berenice Film, which focuses on documentary and audiovisual design. He is also co-founder - with Alessandra Elettra Badoino, Marina Giardina and Fabio Poggi - of Augenblick Associazione Culturale, a video dance collective based in Genoa. Augenblick curates Stories We Dance, the video dance section of FuoriFormato Festival, in Genoa. He collaborates with the Italian online film magazine Filmidee and with the Locarno Film Festival.

Email: augenblick1234@gmail.com

Website: https://augenblick.it/

Ariadne Mikou is a Greek-born artist-scholar currently residing in Italy. She holds a PhD in Interdisciplinary Choreographic Research that was fully funded by the University of Roehampton (UK). With a background as an architect, dance performer and choreographer, her practice is located at the crossover between corporeal, spatial and screen-based arts. She is co-founder of the nomadic micro-festival [SET.mefree] Dance \& Movement on Screen, a platform focused on screendance curation, education and mentoring. Her writing has been published in peer-reviewed international journals and book anthologies. She is a selected artist for Creative Europe's Migrating Artists ProjectChallenging Dance and Cinema across Europe (mAPs). She works at the Department of Philosophy and Cultural Heritage at the University Ca' Foscari of Venice as a Research Fellow for the action-research project Dancing Museums-The Democracy of Beings and as a Research Assistant for the SPIN project Memory in Motion. Re-membering Dance History.

Email: mikouariadne@gmail.com

Website: https://www.amikou.com/

Katja Vaghi is an independent researcher based in Berlin, Germany. She obtained her $\mathrm{Ph} . \mathrm{D}$. in dance philosophy from the University of Roehampton (UK) and is currently a visiting lecturer at several universities and conservatories in the UK and Germany. Her most recent publications include entries on Sasha Waltz for the newest edition of Fifty Contemporary Choreographers (2021) and on Jirí Kylián for The Oxford Handbook of Contemporary Ballet. Her research interests encompass referencing in dance, intermediality, the comic, screendance, and somatic approaches to space. 
Email: kvaghi@yahoo.com

Website: https://katjavaghi.blogspot.com/

\section{Notes}

${ }^{1}$ As well as online conferences and symposiums, Zoom talks and meetings, live and online dance/performance festivals, journal articles and blogs.

${ }^{2}$ And practices of "performative commons"—as suggested by Bench (2020).

${ }^{3}$ In using this term, we recall Virilio's seminal text The Aesthetics of Disappearance (1991) acknowledging the fact that it is a term that emerged in the 1980s, a long time before Instagram (IG) and Facebook (FB) applications appeared. During our discussions, the words "aesthetics of disappearance" came to us instinctually. It is only later during our research that we (re)encountered Virilio's definition. Noteworthy to us is the resemblance to Baldwin's use of Virilio to indicate the "metaphoric potential of media technology, blurring materiality into engines of appearance and delirium" (Baldwin, 137). We connect this with the uses of IG and FB stories seen during spring 2020, especially in the dance and movement field. Witnessing this phenomenon, with thousands of short videos, fragments, TikTok entries appearing and disappearing on our screens, we recalled the logic of acceleration applied by Virilio to technological advancement and each of them as clearly analyzed by Ginette Verstraete for Snapchat, presupposing a different interaction on the part of the audience (IG/FB) or those of the message sender/receiver (Snapchat).

4 This question was the title of the first volume of the International Journal of Screendance.

5 This could refer to human dancers pictured on screen or inanimate object compositions, as well as somatic camera work and choreographic editing.

${ }^{6}$ An example of this can be found in I Miss Outside, an audiovisual contribution of choreographer and professor Rebecca Hilton for her keynote for Modes of Capture Symposium (2020). In her video format presentation, Hilton has framed topics such as "perception, memory, influence, legacy, orality, literacy, ageing, caring, intimacy and uncertainty," into the lens of the screens. The camera was capturing images from a corner in a studio of the Dance Department of Stockholm University of the Arts. From time to time, imposed words in red appeared on the images, such as "I Miss Outside," "Dancerness," in relation to Hilton's audio narration. In this way, the screen is the place where specific feelings and themes have been displaced. In her audiovisual journey, Hilton traces an oral and visual archeology of memory into kinesthetic and life 
experiences, from New York in the late 1980s and Melbourne in the middle 2000s, arriving at a Swedish project for a rest home. Almost at the end of her contribution, to trace the sum total of her experience, she further highlighted how much the present pandemic has shown the extent to which dance needs to remain a local practice and location-in the sense that the first location is the dancer's body-and how much screens took charge of becoming places to be. After the pandemic, she aims for dance production systems to return to "localness," meaning "finding ways to work where we are, figuring out what new modes of capture, new forms of transmission and dissemination may be." Affirming this, she points out how much the internationalness of dance was unsustainable prior to Covid-19.

${ }^{7}$ To cite a sample of examples: Night Creature by Alvin Ailey American Dance, the two different versions of Lo Spettacolo Più Bello Del Mondo by Jacopo Jenna and Marco D'Agostin, Indoors by Scottish Ballet, Willies in Corps-en-Tine by the Australian Ballet and We'll Meet Again by the Drag Queens in Quarantine.

${ }^{8}$ During the first lockdown in Italy, Cinematica festival created a series of calls on a weekly basis under the title Small Contest for Small Dances. Every week curious and restless minds were encouraged to explore in works made for the screen the relationship between the body and furniture, as well as architectural and environmental elements such as chairs, mirrors, carpets, beds, doors, lights, plants, and water. In a similar context, the International Videodance Festival of Burgundy created the open call VidéHomeDance encouraging artists to explore their intimate spaces as lived during the first wave of the pandemic.

${ }^{9}$ Virtual Studies for a Dark Swan by Nora Chipaumire for Opera Estate Festival was created and exclusively rehearsed through digital transmission by the choreographer to the dancers. During the festival, in summer 2020, Virtual Studies for a Dark Swan was performed live before a live and socially distanced audience.

${ }^{10}$ The notion of unproductivity as part of the critique of modernism had gained currency well before the pandemic with significant examples that include, among others, the notion of "unproductive expenditure" as found in the writings of French philosopher Georges Bataille and to a certain degree, the immobility and the non-performance as analyzed in Exhausting Dance and "The Non-time of Lived Experience" by performance scholar André Lepecki. Furthermore, performance and moving-image artist-scholar Claudia Kappenberg in referring to her performance practice often deploys the notion of uselessness "as an antidote and as an attempt to challenge the ubiquitous imperative to work and to always be useful" (643). Through this lens, uselessness and unproductivity should not be confused with laziness. In addition, they should be further differentiated between, on one hand, the forced and involuntarily unproductivity that has been imposed by governmental measures to inhibit the spread of the pandemic and on the other hand, the notion of unproductivity that has been put forward as a choice and as an act of resistance. The former caused artistic production, especially in 
the field of performing arts, to cease or slow down in parts of the world that underwent a lockdown. The latter concerns a proposal against the spirit of neoliberalism and the mechanisms of the goal-driven society, as well as the progress-based and productevaluated economy that all impose a boundless availability for work. Regarding the second option, Jamila Johnson-Small's contribution during the online discussion Performing Solidarity, Ethics and Responsibility that took place during summer 2020 resonates. In this framework and in a call for solidarity, Johnson-Small during the Q\&A suggests a well-embraced proposal by the discussion participants by stating: "What if, we as artists, stop making art for a while? What then? An artists' global, one month, no hour or something. What would we find? What would we come up with, if we would speak to each other in different ways?" This is a provocation that expresses protest and aims to reveal the benefits of art through its temporary absence and withdrawal from everyday life.

${ }^{11}$ Relevant cases in support of this question include the designed for camera streaming of Draw from Within by Wim Vandekeybus for the Rambert Company and the Artangel dance on screen commission Strasbourg 1518.

${ }^{12}$ In DECAMERON PROJECT, participants are based across five continents and their videos 'live' together on one fictional, virtual street: Decameron Row. Every week, a new set of videos is revealed, each indicated by a lit-up window within an illustrated city block. Also, From:Meg Stuart, as part of the CC: World project that was created through multiple contributions in the form of letters in different formats, is related to the field of screendance in a loose sense and supports this question.

${ }^{13}$ While definitions of the political vary, our research returns to the root of the word, as outlined in Marcel Prélot's History of Political Ideas, which underscores how the Greek "polis" or "city" came to represent everything that concerns the city-state, resulting in Aristotle's Politics, one of the most influential texts in the fields of philosophy and political science. According to Aristotle, all communities attempt some good, with the aim of politics being to investigate what makes for good government. Today, for many, the political therefore becomes an act or an aim for greater social, climate, and economic justice. Recent screendance examples created during the pandemic include: Choreographer and Pacific Northwest Ballet dancer Amanda Morgan's Musings, created in collaboration with movement artist Nia-Amina Minor of Spectrum Dance Theater and inspired by a class Morgan had taken on spatial injustice and racism, the non-partisan Dance the Vote project, and the viral documentation of the "Cupid Shuffle" honoring the life of George Floyd. 


\section{References}

"\#ArtistsAreNecessaryWorkers Campaign Video 2020 | Dance/NYC." Posted 14 May 2020. YouTube. https://www.youtube.com/watch?v=gQ7gi8mC-Fw

Baldwin, Sandy. "On Speed and Ecstasy: Paul Virilio's 'Aesthetics of Disappearance' and the Rhetoric of Media." Configurations 10.1 (Winter 2002): 129-148. https://doi.org/10.1353/con.2003.0001

Barnes, Jonathan. Aristotle's Politics. New Jersey and Oxfordshire: Princeton Univ. Press, 2016. https://doi.org/10.23943/princeton/9780691158464.001.0001

Bataille, Georges. "On Nietzsche: The Will to Chance." The Bataillle Reader. Ed. F. Botting and S. Wilson. Oxford: Blackwell Publishers Ltd., 1997.

Bench, Harmony. Perpetual Motion: Dance, Digital Cultures, and the Common. Minneapolis: Univ. of Minnesota Press, 2020. https://doi.org/10.5749/j.ctvxw3p32

Cinematica Festival. "Verso la Transizione." La Mole. Accessed 22 Jan. 2021. https://www.lamoleancona.it/verso-la-transizione-train-announcementpoem/?fbclid=IwAR08sNXxW061ff8u2xfKxPOaxjcCrfCCO4lxMrp4zLenjUp0OgLOxqbaB tc

"Corner Studies." Chor. Trisha Brown. Dev. Trisha Brown Dance Company. Facebook. Posted 14 Oct. 2020. https://www.facebook.com/watch/?v=827447188000970

"Drawn from Within." Dir. and chor. Wim Vandekeybus. Prod. Rambert Company. Rambert Company. Accessed 12 Jan. 2021. https://www.rambert.org.uk/whatson/draw-from-within/

"George Floyd Protesters Dance to 'Cupid Shuffle' During George Floyd Protest in Downtown L.A." Posted 2 June $2020 . \quad$ YouTube. https://www.youtube.com/watch?v=DB8jQM1 bwGU

"Indoors." Chor. Sophie Laplane. Ed. Eve McConnachie. Dir. Christopher Hampson. Perf. Scottish Ballet. Posted 22 July $2020 . \quad$ YouTube. https://www.youtube.com/watch?v=6dqlwFJ4mcc

Kappenberg, Claudia. "The Use of Uselessness." Performing Process. Sharing Dance and Choreographic Practice. Ed. H. Blades and E. Meehan. Bristol and Chicago: Intellect, 2018.

Kubovy, Itamar, Stefanie Sobelle, Juan Diaz Bohorquez and Josef Szuecs. "Decameron Row." The Decameron Row Team. Accessed 12 Jan. 2021. https://www.decameronrow.com/main?mode=nohint

Lepecki, André. Exhausting Dance. New York and Oxon: Routledge, 2006. https://doi.org/10.4324/9780203012871 
---. "The Non-time of Lived Experience: The Problem of Color in Hélio Oiticica's Early Works." Representations $136.1 \quad$ (Fall 2016): 77-95. https://doi.org/10.1525/rep.2016.136.1.77

Lipkin, Joan and Ashley Tate. Dance the Vote. Accessed 31 Jan. 2021. https://www.dancethevotestl.org/

"Lo Spettacolo più Bello del Mondo." Chor. Marco D’Agostin. Cur. Susanne Franco. Prod. Teatro Stabile del Veneto. Facebook. Posted 16 May 2020. https://www.facebook.com/1612082702371867/videos/2990016554380280/

"Lo Spettacolo più Bello del Mondo." Chor. Jacopo Jenna. Cur. Susanne Franco. Prod. Teatro Stabile del Veneto. Facebook. Posted 16 May 2020. https://www.facebook.com/1612082702371867/videos/645291092726189/

"Musings by Amanda Morgan in collaboration with Nia-Amina Minor." Posted 23 July 2020. YouTube. https://www.youtube.com/watch?v=Q9sAbHM2zdE

"Night Creature." Chor. Alvin Ailey. Perf. Alvin Ailey American Dance Theater. Instagram. $\begin{array}{llll}\text { Posted } & 21 & \text { April }\end{array}$ https://www.instagram.com/tv/B_QGeDjHYhP/?utm_source=ig_web_copy_link

"Performing Solidarity Ethics and Responsibility." Org. Noyale Colin and Stefanie Sachsenmaier. Posted 2 July $2020 . \quad$ YouTube. https://www.youtube.com/watch?v=xOJq_dQSJJ8

Prélot, Marcel and Georges Lescuyer. Histoire des Idées Politiques. Paris: Dalloz, 1997.

"Rebecca Hilton | I Miss Outside | Keynote | Modes of Captures Symposium 2020." Posted 12 June 2020. YouTube. https://www.youtube.com/watch?v=hhja5-ojns4

"ResiliArt - A Global Movement for Artists." Prod. Unesco. Posted 14 April 2020. YouTube. https://www.youtube.com/watch?v=-xl7jJxoOa8

Rosenberg, Doug and Claudia Kappenberg. "Screendance: The Practice in Print." The International Journal of Screendance 1 (2010): 1-4. https://doi.org/10.18061/ijsd.v1i0.6380

Scherer, Bernd. "Cc:World." Haus der Kulturen der Welt. Accessed 22 Jan. 2021. https://ccworld.hkw.de/\#inbox

Strasbourg 1518. Dir. Jonathan Glazer. Comm. Artangel and Sadler's Wells. Prod. Academy Films for BBC Films and BBC Arts. Artangel. Accessed 12 Jan. 2021. https://www.artangel.org.uk/project/strasbourg-1518/

Stuart, Meg. "From: Meg Stuart." CC: World. Accessed 22 Jan. 2021. https://ccworld.hkw.de/\#meg-stuart 


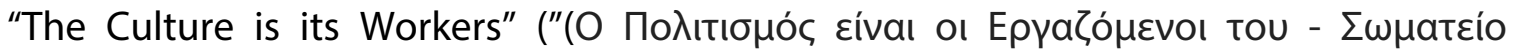

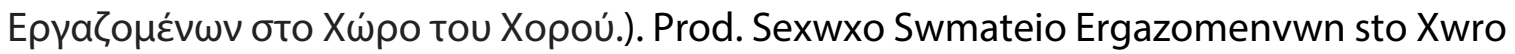
tou Xorou. 2020. YouTube. https://www.youtube.com/watch?v=|fbRs8vlttH4\&t=2s

Verstraete, Ginette. "It's about Time. Disappearing Images and Stories in Snapchat." Image [\&] Narrative 17.4 (2016): 104-13.

"VidéHomeDance Project." Dev. International Videodance Festival of Burgundy. Facebook. Posted 2020. https://m.facebook.com/watch/?v=870192576789246\&_rdr

Virilio, Paul. The Aesthetics of Disappearance. Trans. P. Beitchman. Cambridge, MA: MIT Press, 1991.

Virtual Studies for a Dark Swan. Chor. Nora Chipaumire. Prod. Opera Estate Festival 40. Opera Estate Festival 40. Accessed 12 Jan. 2021. https://www.operaestate.it/it/8eventi/3076-dark-swan-for-bassano-3

"We'll Meet Again - Vera Lynn, Drag Queens in Quarantine (DiQ)." Posted 17 April 2020. YouTube. https://www.youtube.com/watch?v=mdZXQHa9rv0

"Willies in Corps-en-Tine." Chor., dir. Danielle Rowe and Garen Scribner. Ed., prod. Reneff-Olson. Perf. The Australian Ballet. Facebook. Posted 15 May 2020. https://www.facebook.com/watch/?v=332952011017215 